\title{
UPTAKE AND STORAGE MECHANISM OF 5-HYDRO- XYTRYPTAMINE IN RABBIT BRAIN STEM AND EFFECT OF RESERPINE
}

\author{
Katsuya TAKATSUKA, Tomio SEGAWA and Hiroshi TAKAGI \\ Deparment of Pharmacology, Facully of Pharmaceutical Sciences, \\ Kyoto University, Sakyo-ku, Kyoto
}

Received for publication July 21,1970

In a previous paper (1) 10 clarify the physiological significance of endogenous 5-hydroxytryptamine (5-HT) the subcellular distribution of 5-HT in rabbit brain stem has been studied and the electron microscopical structures of the fractions which contain 5-HT have been examined. 5-HT was principally found in $\vec{r}_{3}$-fraction which consisted largely of mitochondria and nerve-ending particles (NEPs). After density-gradient centrifugation 5-HT was found to be comparatively highly concentrated in NEPs-fraction $\left(\mathbf{P}_{2} \mathbf{B}-\right.$ fraction). On the other hand suspension of $\mathrm{P}_{2}$-fraction in hypo-osmotic medium and subsequent differential centrifugation resulted in high concentration of 5-HT in synaptic vesicles (sv) fraction although considerable amount of $5-\mathrm{HT}$ was also found in $\mathbf{P}_{2} \mathrm{D}-$ and $\mathbf{P}_{2}$ S-fraction. In general 5-HT in brain stem was not so highly concentrated in specific fraction as with the distribution of acetylcholine (ACh) $(2,3)$ but rather diffusibly distributed among several fractions.

In this paper the role of 5-HT in synaptic transmission, espccially in central nervous system was investigated mainly through the experiments on 5-HT uptake by subcellular fraction of rabbit brain stem. The chemical transmission at synapses consists of the following consecutive steps: $I$ ) release of transmitter by synaptic impulses. 2) combination of transmitter with postsynaptic receptor. 3) generation of impulses by postsynaptic potential. It appears that the study into the formation, uptakc, storage, release and inactivation of 5-HT is necessary for full and accurate understanding of mechanism of chemical transmission, especially when there is no direct evidence for that 5-HT is synaptic transmitter in central nervous system. Segawa and Kuruma (4), Segawa ct al. (5) in this laboratory have already shown that NEPs or sv of brain, when incubated in a medium containing 5-HT, could take up 5-HT from the medium and some drugs could inhibit the uptake of 5-HT. However we have as yet very little information as to whether NEPS or sv are specific uplake and storage site for 5-HT in situ. Also the mechanisms with which amine can be taken up by synapses and drug inhibits the uptake are poorly under-

Reprints requests and enquiries should be sent to Tomio Segawa, Department of Pharmacology, Faculty of Pharmaceutical Sciences, Kyoto University, Sakyo-ku, Kyoto.

The results were briefly presented at a Regional Meeting of the Japanese Pharmacological Society at Kyoto on July, 13, 1968. 
stood. The following is a systematic study concerning the mechanism of 5-HT uptake and drug effect.

\section{MATERIALS AND METHODS}

Male and female rabbits, weighing about $2.5 \mathrm{~kg}$ were used. One to three brain stems (ea. $2.5-7.5 \mathrm{~g}$ ) were homogenized in ice cold $0.32 \mathrm{M}$ sucrose using a Teflon pestle with two to throe up-and-down motions of the mortar during preparation. The time for homogenization was not restricted. The method of fractionation was based on that previously employed in this laboratory $(4,5)$. The subcellular fractions were suspended in KrebsRinger phosphate buffer ( $\mathrm{pH}$ 7.4) of the following composition: $140 \mathrm{~mm}-\mathrm{Na}^{+}, 6.0 \mathrm{~mm}-\mathrm{K}^{+}$, $2.7 \mathrm{~mm}-\mathrm{Ca}^{2+}, 1.2 \mathrm{~mm}-\mathrm{Mg}^{2+}, 130 \mathrm{~mm}-\mathrm{Cl}^{+}, 18 \mathrm{~mm}^{2+} \mathrm{PO}_{4}{ }^{3+}, 1.2 \mathrm{~mm}-\mathrm{SO}_{4}{ }^{2+}, 10 \mathrm{~mm}$-glucose. An aliquot $(4.4 \mathrm{ml}$ or $4.6 \mathrm{ml}$ ) of suspension was transferred to a $30 \mathrm{ml}$ of Erlenmeyer flask and incubated with $0.2 \mathrm{ml}$ of pheniprazine (final concentration of $5 \times 10^{-3} \mathrm{M}$ ) for 30 minutes in air at $37^{\circ} \mathrm{C}$ with $70-80$ shaking per minute. After incubation $0.2 \mathrm{ml}$ of a solution of 5-HT and $0.2 \mathrm{ml}$ of a solution of drug to be tested in Krebs Ringer phosphate bufler solution were added and incubated for a further 30 minutes at $37^{\circ} \mathrm{C}$. Thereafter the mixtures were centrifuged as the method of subfractionation. The pellet was washed twice with $0.32 \mathrm{M}$ sucrose solution at $0{ }^{\circ} \mathrm{C}$.

When $P_{2} V(s v)$-fraction was used directly in the experiment, the fraction was suspended in isotonic modified Krebs solution $\left(\mathrm{NaCl} 6.90 \mathrm{~g} ; \mathrm{KCl} 0.35 \mathrm{~g} ; \mathrm{CaCl}_{2} 0.28 \mathrm{~g} ; \mathrm{MgCl}_{2} 0.11\right.$ $\mathrm{g}$; $\mathrm{NaH}_{2} \mathrm{PO}_{4} 0.14 \mathrm{~g}$; glucose $2.00 \mathrm{~g}$ in $1000 \mathrm{ml}$ of glass distilled water) without pre-incubation with pheniprazine.

The protein content was estimated by the method of Lowry et al, (6) with slight modification. 5-HT was extracted and assayed fluorimetrically by the method of Snyder et al. (7).

Materials used were 5-hydroxytryptamine creatinine sulfate (Nakarai Chemical Co.), pheniprazine (Chugai Seiyaku, Co.), 5-hydroxytryptophan (Nakarai Chemical Co.) and reserpine (Nihon Shinyaku, Co.).

\section{RESULTS}

1. Subcellular distribution of 5-HT aficr calministration of 5-hydroxytryptophan (5-HTP) and pheniprazine

Our findings reported previously (1) have shown that 5-HT was not so highly concentrated in $\mathrm{P}_{2}$ B-fraction which consisted almost entirely of NEPS, although concentration of 5-HT per protein in this fraction increased when this fraction was re-centrifuged. From this result it is difficult to draw the conclusion that NEPs are the specific storage site for 5-HT. Therefore in an attempt to obtain more evidence for this problen 5-HT synthetic ability of each fraction was examined.

The subcellular distribution of endogenous 5 -HT in rabbit brain stem was presented in Table 1, Column 1. The effect of pheniprazine ( $3 \mathrm{mg} / \mathrm{kg}$, i.v., 15 minutes) on the concentration and distribution of 5-HT in brain stem was given in Table 1, Column 2. Col- 
TABLE 1. Subceltular distribution of $5-H T$ in rabbit brain stem after intravenous administration of pheniprazine or pheniprazine and 5-HTP.

\begin{tabular}{|c|c|c|c|c|c|c|}
\hline \multirow{2}{*}{ Fraction } & \multicolumn{2}{|c|}{ Treatment } & \multirow{2}{*}{$\begin{array}{l}\text { Ratio } \\
\text { (II/1) }\end{array}$} & Treatment & \multirow{2}{*}{ III-II } & \multirow{2}{*}{$\begin{array}{c}\mathrm{IHI}-\mathrm{II} \\
\mathrm{I}\end{array}$} \\
\hline & I: None & II: MAOI* & & III: $\mathrm{MAOI}+5-\mathrm{HTP}^{* * *}$ & & \\
\hline & \multicolumn{2}{|c|}{ (ng/g tissue) } & & \multicolumn{3}{|c|}{ (ng/g tissue) } \\
\hline$P_{1}$ & 26.6 & 46 & 1.72 & 90 & 44 & 1.69 \\
\hline $\mathrm{P}_{3}$ & 242.5 & 392 & $1.6 \mathrm{i}$ & 2360 & 2068 & 8.50 \\
\hline$P_{3}$ & 36.5 & 158 & 4.33 & 660 & 502 & 13.70 \\
\hline $\mathbf{S}_{i ;}$ & 152.5 & 580 & 3.80 & 4620 & 4040 & 26.50 \\
\hline$P_{s-A}$ & 64.9 & 194 & 2.99 & 851 & 621 & 9.58 \\
\hline$P_{:-B}$ & 76.8 & 155 & 2.02 & 1320 & 1165 & 15.20 \\
\hline $\mathrm{P}_{2}-\mathrm{C}$ & 31.9 & 45 & 1.42 & 56 & 11 & 0.35 \\
\hline
\end{tabular}

* Pheniprazine $3 \mathrm{mg} / \mathrm{kg}$

:HTP $40 \mathrm{mg} / \mathrm{kg}$

umn 4 in Table 1 showed the results of the experiment in which rabbit was trated with 5 -IITP (40 $\mathrm{mg} / \mathrm{kg}, \mathrm{i} . v$.) 5 minutes after the administration of pheniprazine ( $3 \mathrm{mg} / \mathrm{kg}$, i.v.) and was killed 20 minutes later. The value of II/I shown in Table 1, Column 3 represented relative increase in 5-HT content after monoamine-oxidase inhibitor (MAOI) and this was thought to give some indication of 5-HT synthetic ability of each fraction.

The value of $111-11 / 1$ given in Table 1 , Column 6 which was considerably high in $P_{3}$-, $S_{3}$ - and $P_{2} B-f r a c t i o n$ and relatively high in $P_{2} A$-fraction was regarded as the uptake- and synthetic-ability of 5-HT.

\section{5-HT uptahe by subcellular fractions}

The primary fractions, $P_{1}, P_{2}$ and $P_{3}$ were suspended in Krebs Ringer phosphate buffer

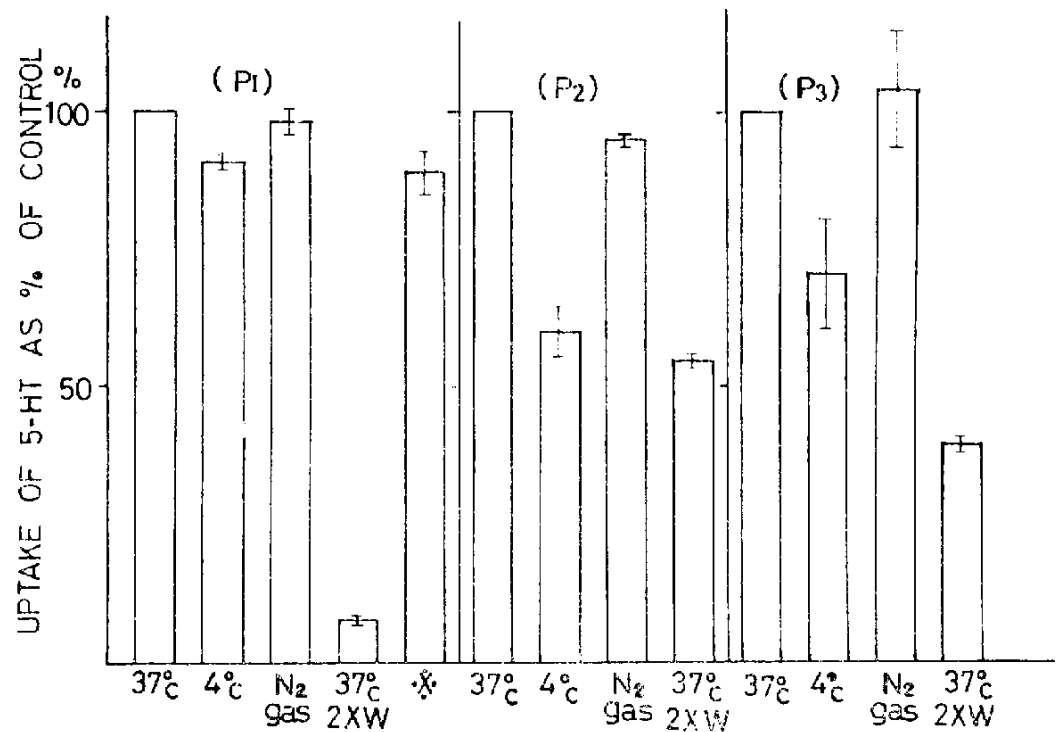

Fic. 1. Uptake of 5-HT by subcellular fractions from rabbit brain stem homogenates. Each fraction was incubated with $5 / 2 \mathrm{~g} / \mathrm{ml}$ of $5-\mathrm{HT}$.

2XW: washed twice with $0.32 \mathrm{M}$ sucrose solution at $0 \mathrm{C}$.

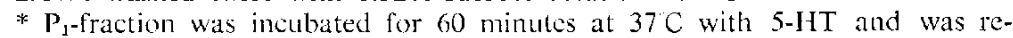
incubated after 2 times washing with ice cold $0.32 \mathrm{M}$ sucrose solution. 
solution ( $\mathrm{pH} 7.4$ ) and were incubated with 5 -HT (final concentration of $5 \mu \mathrm{g} / \mathrm{ml}$ ). As was shown in Fig. $1 \mathrm{P}_{1}$-fraction took up practically same amount of 5 - $\mathrm{HT}$ both at $4^{\circ} \mathrm{C}$ and $37 \mathrm{C}$ in air and at $37^{\circ} \mathrm{C}$ in nitrogen gas. Furthermore nearly all of 5-HT taken up at $37^{\circ} \mathrm{C}$ could be readily removed by washing twice with cold 5 -HT-free $0.32 \mathrm{M}$ sucrose and again they could take up almost the same amount of 5-HT when they were incubated with 5 HT. These observations suggest that the uptake of 5-HT by $P_{1}$-fraction in vitro was nonspecific in nature.

On the other hand $\mathrm{P}_{2}$-fraction could take up much more quantity of $5-\mathrm{HT}$ at $37^{\circ} \mathrm{C}$ than at $4 \mathrm{C}$ (Fig. 1) and this could not casily be removed by washing at $4 \mathrm{C}$. This result would indicate that the uptake of 5-HT by $P_{2}$-fraction was rather specific. $P_{3}$-fraction also took up 5-HT in similar fashion. This result is in good agrecment with those of Inouye et al. (8), Gillis et al. (9) and Robinson et al. (10). However as $\mathbf{P}_{3}$-fraction consisted of microsomal particles and was devoid of NEPs the physiological significance of this uptake and the mechanism which involved in this uptake must be different from that of $P_{2}$-fraction. Because NEPs was abundant in $P_{y}$-fraction it is reasonable to presume that large proportion of 5-HT which was taken up by $\mathbf{P}_{2}$-fraction was incorporated into NEPs. The question now arises as to the possible source of energy for the uptake of 5-HT by $\mathrm{P}_{\mathrm{z}}$ - or $P_{3}$-fraction because the uptake was unaffected by $\mathrm{N}_{2}$ gas. Further studies into this problem are necessary.

Our previous results $(4,5)$ in which NEPs and sv were found to be able to take up 5-HT from the medium do not per se mean that these structures are the storage sites for 5-HT. To observe how much proportion of 5-HT which was taken up by $\mathrm{P}_{2}$-fraction was associated with sv fraction the following experiments were performed. The $P_{2}$-frac-

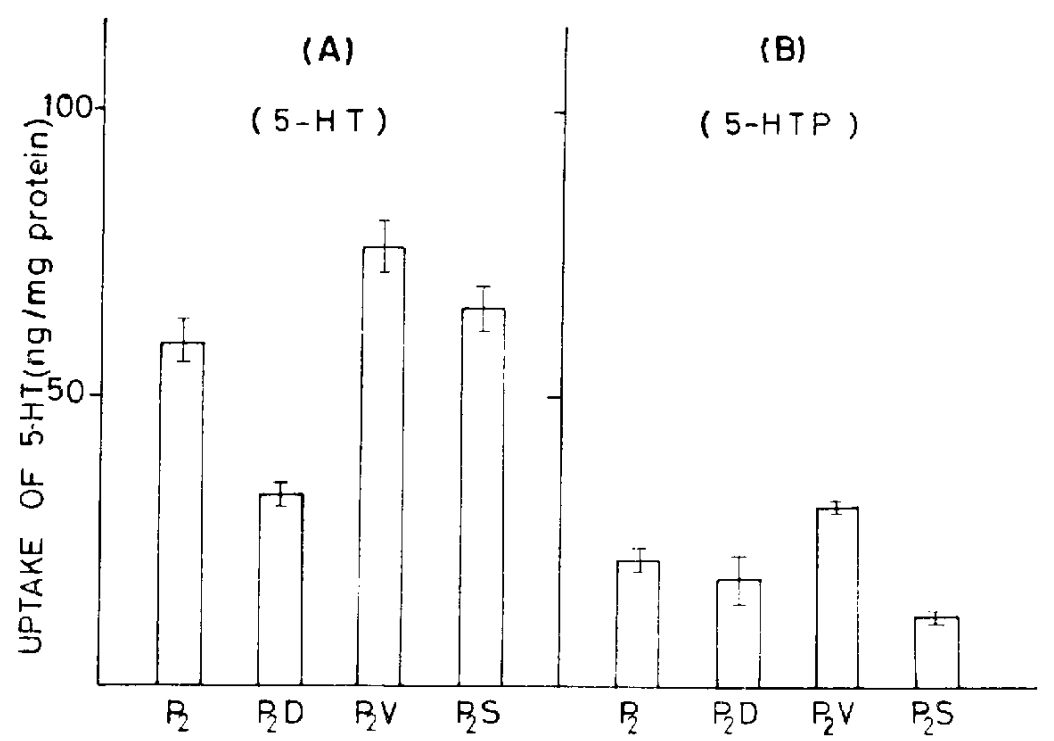

Fig. 2.. Accumulation of 5-HT in $P_{2}$-fraction after incubation with $5-\mathrm{HT}(5 \mu \mathrm{g} / \mathrm{ml})$ or 5-HTP $(5 \mathrm{rg} / \mathrm{ml})$. P $P_{2}$-fraction was subfractionated into $\mathrm{P}_{2} \mathrm{~V}-, \mathrm{P}_{2} \mathrm{~S}-$ and $\mathrm{P}_{2} \mathrm{D}-$ fraction after incubation. 
tion suspended in Krebs Ringer phosphate buffer solution ( $\mathrm{pH} 7.4$ ) was incubated with $5-\mathrm{HT}$ (final concentration of $5 \mu \mathrm{g} / \mathrm{kg}$ ) at $37 \mathrm{C}$ for 30 minutes, centrifuged at $11,500 \mathrm{~g}$ for 20 minutes and the yielded pellet was washed with $0.32 \mathrm{~m}$ sucrose at $0^{\circ} \mathrm{C}$. The pellet was then submitted to hypo-shock and then subrfactionated in the usual manner. The results in Fig. 2, Section A showed that the concentration of 5-HT in $\mathrm{P}_{2} \mathrm{~V}$-fraction containing sv was highest among three subfractions.

Rate of uptake of 5-HT by sv as a function of time was shown in Fig. 3. The uptake was fast: after 5 minutes of incubation the amount of $5-\mathrm{HT}$ in the fraction was $75 \%$ of that after 30 minutes. In Figs. 4 and 5 the uptake of 5-HT by $\mathrm{P}_{2} \mathrm{~V}$ - and $\mathrm{P}_{2} \mathrm{~S}$-fraction was plotted against the concentration of 5-HT in the medium. At low 5-HT concentration in medium the amounts of 5-HT taken up by the fractions were almost proportional to the concentration of exogenous 5-HT but showed the tendency to approach the plateau in the concentration range of $5 / \mathrm{g} / \mathrm{ml}$. There was similarity between 5-HT uptake by $P_{2} Y$ - and $P_{2} S$ fraction in relation to the absolute quantity of 5-HT in fraction and the rate of uptake of 5-HT as a function of 5-HT concentration in medium although 5-HT concentration per protein in $\mathrm{P}_{2} \mathrm{~V}$-fraction was slightly higher than in $P_{i d} S$-fraction. This result might be in conflict with the

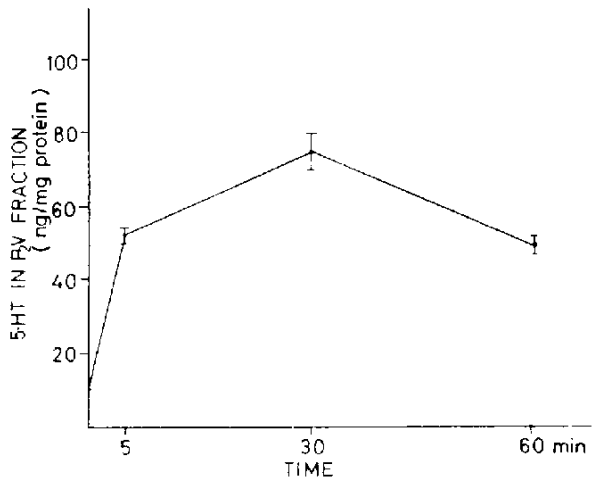

Fici. 3. Rate of uplake of 5-HT as a function of time by $P_{2} V$-fraction. $P_{2}$-fraction was incubated with $5-\mathrm{HT}(5 \mathrm{gg} / \mathrm{ml})$ and then subfractionated into $\mathrm{P}_{2} \mathrm{~V}$-fraction.

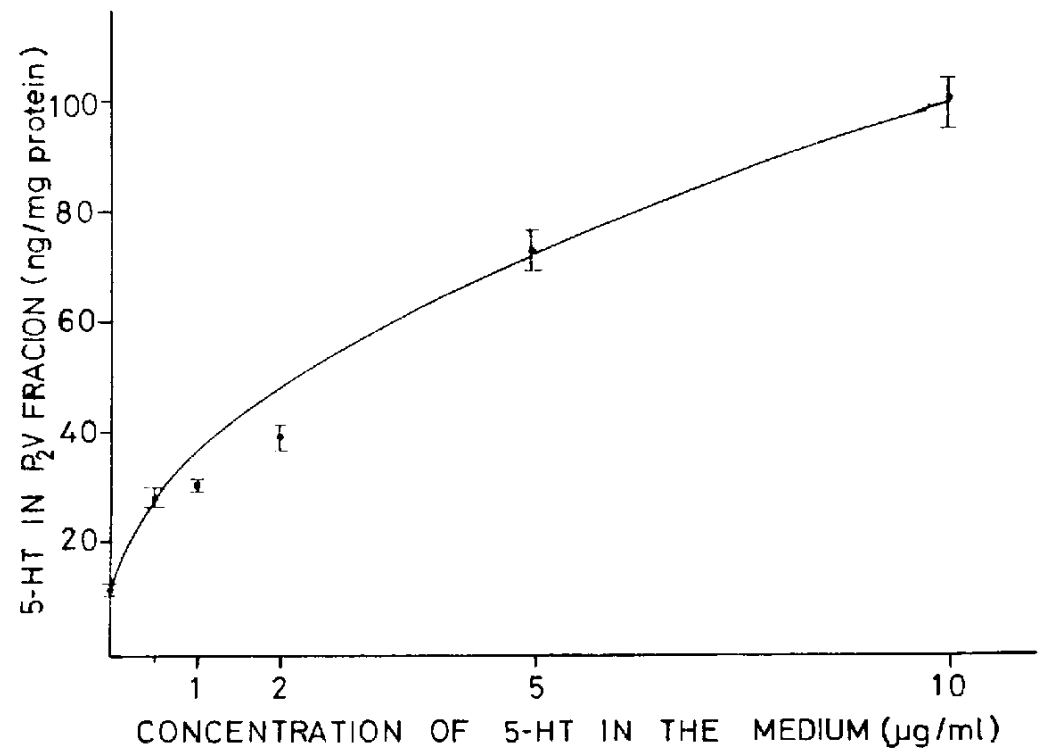

Frg. 4. Uptake of 5-HT by $P_{2} V$-fraction. $P_{2}$-fraction was incubated with 5-HT (5 $r \mathrm{~g} / \mathrm{ml})$ and then subfractionated into $\mathrm{P}_{2} \mathrm{~V}$-fraction. 


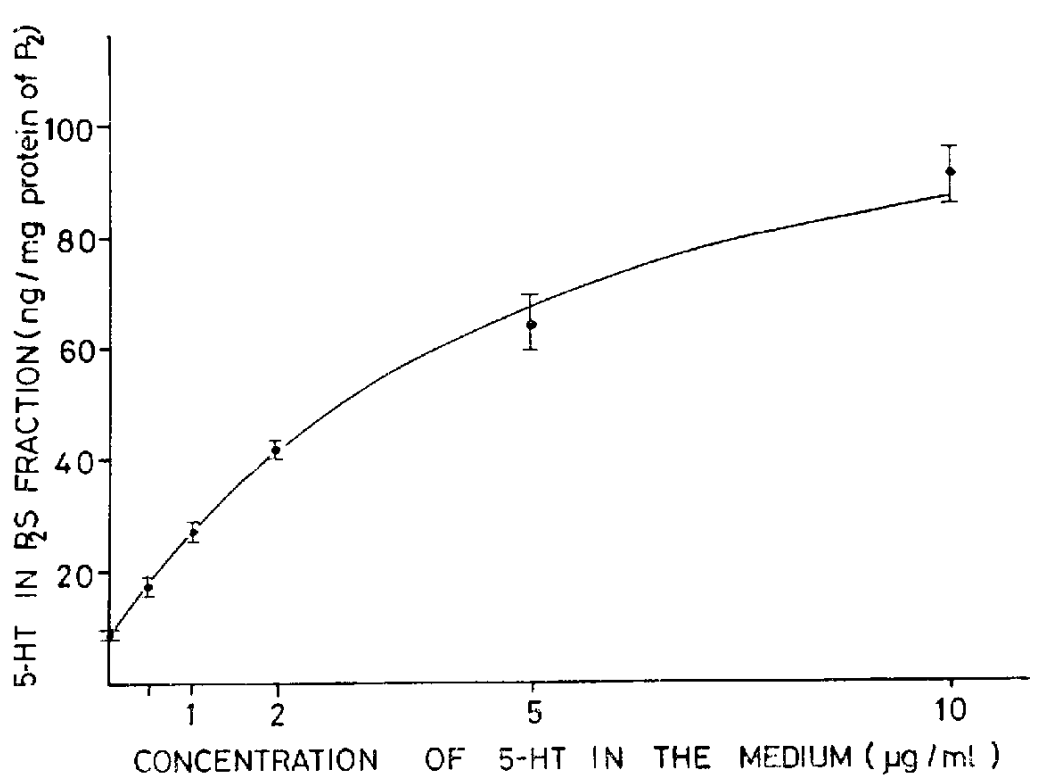

FIG. 5. Uptake of 5-HT by $P_{3}$ S-fraction. P $P_{2}$-fraction was incubated with 5-iHT (5 $f: g / n 1)$ and then subfractionated into P.S-fraction.

view that $\mathrm{sv}$ is the specific storage site for 5-HT. However it should be laken into account that the fraction was treated with MAOI which inhibited the metabolic destruction of any 5-HT taken up into axoplasm. Without MAOl 5-HT concentration in PS fraction should decrease.

$P_{2}$-fraction was also subiected to incubation with 5-HTP (final concentration of 5 $\ell \mathrm{g} / \mathrm{ml}$ ) and was then subfractionated into $\mathrm{P}_{2} \mathrm{~V}-, \mathrm{P}_{2} \mathrm{~S}-$ and $\mathrm{P}_{2} \mathrm{D}$-fraction. It was found that less amount of 5-HT was taken up than in the experiment in which $P_{2}$-fraction was incubated with 5-HT (Fig. 2, Section A. B). If the endogenous amount of 5-HT was subtracted from 5-HT concentration after incubation the remaining value was almost negligible, indicating that actually no uptake occurred (Fig. 2, Section B). This indicates that originally 5-HT, but not 5-HTP can be taken up into the synaptic region and that accumulation of 5-HT at sv is taken up as 5-HT itself.

\section{Effect of $\mathrm{pH}$ on 5-HT uplake by $\mathrm{P}_{2} \mathrm{~V}$-fraction}

The isolated $P_{2} V$-fraction was suspended in isotonic modified Krebs solution of various $\mathrm{pH}$ with $5-\mathrm{HT}$ at $37^{\circ} \mathrm{C}$ for 60 minutes. The result in Fig. 6 showed that the uptake was greally affected by $\mathrm{pH}$, it increased with increasing $\mathrm{pH}$ of the medium $(\mathrm{pH} 8.5)$ and decreased with decreasing $\mathrm{pH}$ of the medium (pH 5.7). After large amount of 5-HT was taken up by $\mathrm{P}_{2} \mathrm{~V}$-fraction at $\mathrm{pH} 8.5$ the incubation medium was centrifuged to yield $\mathrm{P}_{2} \mathrm{~V}$ pellet. Thereafter the pellet was either washed twice with ice-cold anine free-medium of $\mathrm{pH} 8.5$ or of $\mathrm{pH} 5.7$ or incubated in the medium of $\mathrm{pH} 5.7$ at $0^{\circ} \mathrm{C}$ for 30 minutes. No apparent difference in the remaining quantity of 5-HT in $\mathrm{P}_{2} \mathrm{~V}$-pellet was detected. From this result it is suggested that the uptake is not a non-specific ionic binding of 5-HT to the surface of sv. 


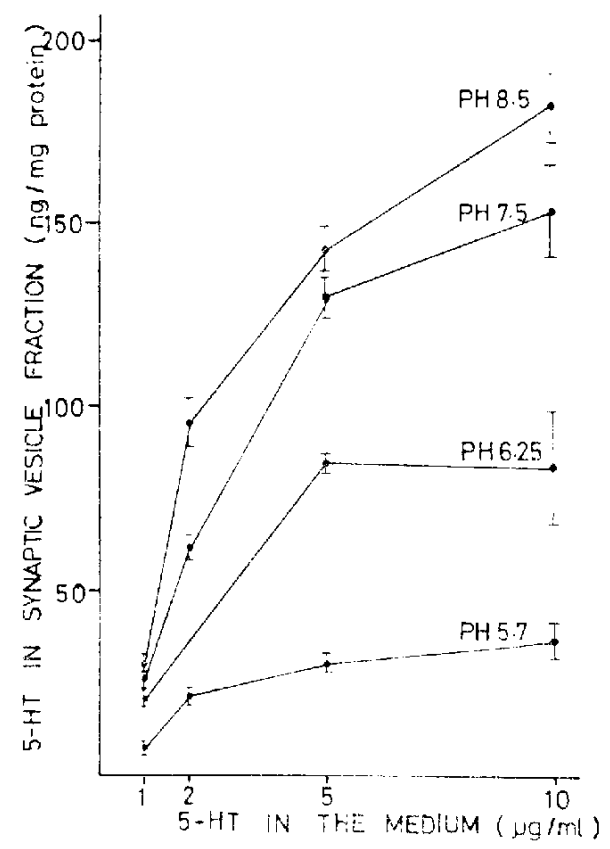

Fir. 6. Effect of medium pH on uptake of 5-HT by 5-HT P. V-fraction.

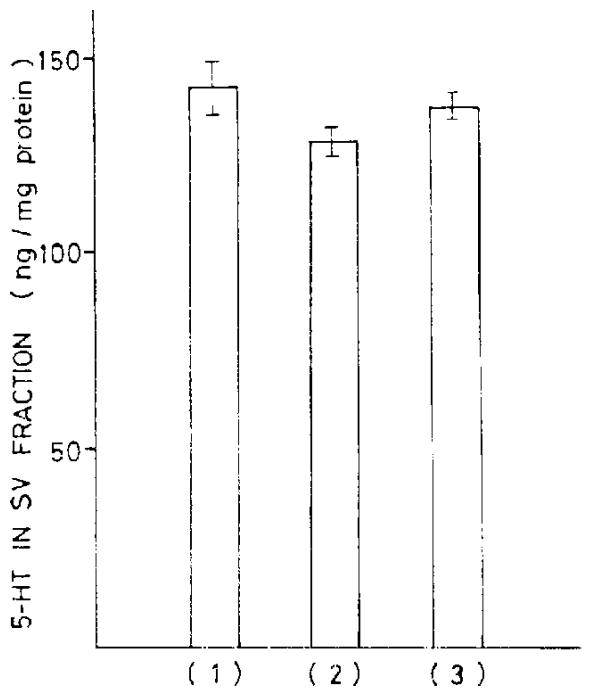

Fia, 7. Eifect of $\mathrm{pH}$ of washing- and reincubation-medium on uptake of 5 -HT by P. V-fraction. $P_{2} V$-fraction was incubated with 5 -HT $(5, \mathrm{~g} / \mathrm{m})$ for 60 minutes at $37 \mathrm{C}$ in $\mathrm{pH} 8.5$ isotonic modificd Krebs solution and was tratud in the lollowing manner.

(1): washed two times with $\mathrm{pH} 8.5$ solution.

(2): washed two times with pH 5.7 solution.

(3): reincubated for 30 minutes at 00 in $\mathrm{plt} 5.7$ solution.

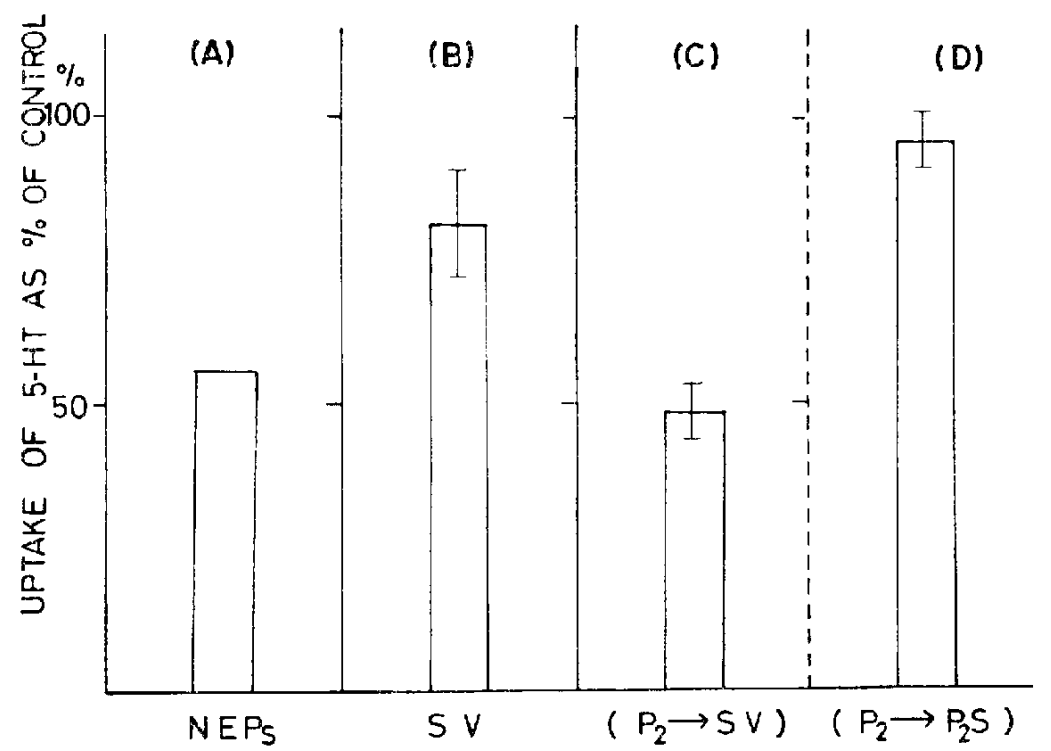

FrG. 8. Fffect of reserpine on uptake of 5-HT. P $P_{2-}$, NEPs-and SV-fraction were incubated with $5-\mathrm{HT}(5 \mathrm{~g} / \mathrm{ml})$ in the presence of $\mathrm{rescrpine}(20 \mathrm{~kg} / \mathrm{ml})$. $\mathrm{P}_{2-}$ fraction was then treated in the usual manner to obtain SV-and Pas-fraction. 


\section{Effect of reserpine}

As to the site of action of reserpine many authors (11-14) have favoured the view that reserpine selectively blocks the incorporation of 5-HT into storage granule although there is objection (15) to this vicw. To obtain more direct information about the site of reserpine action $P_{2}$-fraction was incubaled with 5-HT in the presenceof reserpine (final concentration of $20 \mathrm{~g} / \mathrm{g} / \mathrm{ml})$ and was then treated in the usual manner to yield $P_{2} V$ - and $\mathrm{P}_{2} \mathrm{~S}$-fraction. The results in Fig. 8 , Section $\mathrm{C}, \mathrm{D}$ showed that the uptake by $\mathrm{P}_{2} \mathrm{~V}$-fraction was significantly inhibited by reserpine while that of $\mathrm{P}_{2} \mathrm{~S}$-fraction was not greatly affected. These results, together with our previous findings $(4,5)$ (presented in Fig. 8, Scction A, B) give more clear evidence that rescrpine acts mainly at the level of sv. As presented in Fig. 8 5-HT uptake was inhibited more prominently in NEPs-farction than in isolated $P_{2}$ V-fraction. This may be explained in two ways: 1) reserpine needs some components in axoplasm in order to cxhibit its action. 2) reserpine sensitive site which is supposed to localize at synaptic vesicle membrane is injured by subfractionation process.

\section{DISCUSSION}

If one make an attempt to identify some substance as chemical transmitter in central nervous system one should take the following two problems into account: I) the question whether there exists regional specificity of the corresponding transmitter uptake and storage in a brain. Can 5-HT-, noradrenaline (NE)-, dopamine (DA)- and ACh-neurons have a high specificity in respect of the uptake and storage of the corresponding amines? 2) the question whether there is regional specificity within one neuron with respect to site and form of amine storage, mechanism and site of amine uptake. The present study was undertaken mainly to examine the latter problem.

Unfortunately the brain stem homogenate used in this experiment is by no means homogeneous. It contains not only serotonergic but catecholaminergic terminals as well. Therefore the accurate results are not expected unless more homogeneous preparation is available. In an attempling to approach the problem /) described above, in a previous paper (16) the crude mitochondrial fractions derived from hypothalamus, corpus striatum and cerebellum of rabbit were incubated with 5-HT, together with or without NE or DA. It was found that there was a considerable degree of regional specificity in the uptake of 5-HT by 5-HT terminal since exogenous 5-HT was mostly taken up by terminals from area rich in endogenous 5-HT. Also the uptake of 5-HT by terminals containing NE and DA was found to be inhibited by NE and DA considerably. From this result it may be implied that the uplake of 5-HT by serotonergic nerve terminal in vitro is specific in nature although it was inhibited with NE or DA to some degree. This result also could give some answer to the question l) mentioned above.

There were marked increases in 5-HT concentration in $P_{3^{-}}, S_{i^{-}}, P_{2} A-$ and $P_{2} B-f r a c-$ tion when rabbit was trated with pheniprazine alone or pretreated with pheniprazine followed by 5-HTP. $P_{s^{-}}$and $S_{3}$-fraction are largely derived from cell body and axon. $P_{2} B$-fraction consists almost cntirely of NEPS while $P_{2} \wedge$-fraction comprizes myclin frag- 
ments with or wilhout attached axons in which vesicular structures were observed (1).

When $\mathrm{P}_{2}$-fraction was incubated with 5-IITP only negligible amount of 5-HT was found to be accumlated in $P_{2^{-}}, P_{2} V$ - and $P_{2} S$-fraction. This result, together with Segawa's result (17) in which intravenous injection of 5-HTP resulted in largest increase in $\mathrm{S}_{3}$-fraction in 5-HT concentration followed by the increase in $\mathbf{P}_{3^{-}}, \mathbf{P}_{2^{-}}$and $\mathbf{P}_{1}$-fraction supports the view that 5-HTP from circulation is first accumulated in the cell body, decarboxylated to 5-HT and then transported down to the terminal.

Robinson et al. (10) have reported that when NEPs were incubated with $C^{14}-5$-HTP in a medium which contained brain supernatant fraction (equivalent to $\mathrm{S}_{3}$-fraction in our experiment) less 5-HT was taken up than in experiment in which $\mathrm{C}^{14}-5$-HT was added. They explained that part of this was due to the addition of the brain supernatant fraction. Our experiment, however, showed that NEPs in Krebs solution could not take up large amount of 5-HTP. Therefore some additional mechanism must be involved.

As with $P_{2}$-fraction, $P_{3}$-fraction could also take up 5-HT in a similar fashion. At present it seems difficult to draw the conclusion that the mechanism involved in 5-HT uptake by $P_{3}$-fraction is different from that by $P_{2}$-fraction. However Segawa's report (17) in which when MAOI was injected into the reserpine treated rabbit, remarkable restoration of increase in 5-HT concentration after 5-HTP administration was obtained in $\mathrm{P}_{2}$ fraction but not in $\mathrm{P}_{3}$-fraction might suggest that some different mechanism exists.

The effect of mediun $\mathrm{pH}$ on 5-HT uptake by $\mathrm{P}_{2}$-fraction has been discussed by many authors. Wise et al. (18), Robinson et al. (10) have found that the uptake increased with increasing pH of the medium. Furthermore Robinson et al. (10) have shown that the uptake of 5-HT by NEPs was inhibited by increasing concentrations of hydrogen ions, divalent and monovalent cations and they suggested that cations were compeling with the positively charged amine for binding sites on the NEPs, analogous to an ion-exchange process. However in the system of Wise and Ruclius (18) NE and histamine (both are cations at $\mathrm{pH} 8.0$ ) were bound to a considerably lesser extent than 5-HT. Our results in which 5-HT taken up by $\mathrm{P}_{2} \mathrm{~V}$-fraction at $\mathrm{pH} 8.5$ could not be removed by the nedium of $\mathrm{pH} 5.7$ or by incubating in this medium at $0 \mathrm{C}$ for 30 minutes appear to be at variance with the view that the binding of 5-HT is solely ion-exchange process. Furthermore as $\mathrm{pH}$ 8.5-10 is far from physiological condition the binding of 5-HT in such pH seems not significant physiologically.

Electronmicroscopic observations revealed that synaptic vesicles have vesicle membrane $(1,19,20)$. There are two possible mechanisms for the binding of 5 -HT to sv: I) 5 -HT is solely bound to the outer surface of vesicle membrane electrically or chemically. 2) 5-HT is taken up within sy through vesicle membrane and is stored there in a free form or in a binding form with specific substance. In adrenal medullary granule 5-HT has been found to be bound to ATP (21 24) while in mast cell granule it has been known to be bound to heparin (25-29). From our present results it is suggested that mechanism 2) is involved in the uplake of 5-HT by sv.

Two different amine uptake mechanisms have been presented in adrenergic neurons: 
active transport through neuronal membrane and subsequent incorporation into storage granules $(11,30,31)$. The same may be said of the uptake of 5-HT by sv: transport through membrane of $\mathrm{sv}$ and concentration (storage) within sv. Thus, irrespective as to whether sv take up 5-HT by passive diffusion- or active transport-process 5-HT will be taken up and stored within $\mathrm{sv}$ to its storage capacity. The details of this mechanism remain to be determined.

\section{SUMMARY}

1. When rabbit was treated with MAOI alone or pretreated with MAOI followed by 5-HTP marked increase in 5-HT concentration in $P_{3^{-}}, S_{3^{-}}, P_{2} A-$ and $P_{2} B$-fraction from brain stem was observed.

2. $P_{1}$-fraction could take up $5-H T$ in vitro but the uptake was temperature insensitive and nearly all of 5-HT taken up at $37^{\circ} \mathrm{C}$ could be readily washed out.

3. The uptake of 5-HT by $\mathrm{P}_{2}$-fraction was temperature dependent and the amine taken up at $37^{\circ} \mathrm{C}$ could not easily be removed by washing. $P_{3}$-fraction also took up 5$\mathrm{HT}$ in similar fashion.

4. 5-HT bound to $P_{2}$-fraction in vitro was found to be mainly associated with $P_{2} V$ fraction and was more concentrated than in $\mathrm{P}_{2}$-fraction.

5. The rate of uptake of 5-HT by sv was fast. At low 5-HT concentration in medium the amount of 5-HT taken up by $\mathrm{P}_{2} \mathrm{~V}$ - and $\mathrm{P}_{3} \mathrm{~S}$-fraction was almost proportional to 5-HT concentration in medium.

6. $\mathrm{P}_{2}$-fraction, when incubated with 5-HTP took up less amount of 5-HT.

7. The uptake of 5-HT by $P_{2} V$-fraction was allected by pH, it increased with increasing $\mathrm{pH}$ of the medium, decreased with decreasing $\mathrm{pH}$ of the medium.

8. Reserpine was found to act mainly at the level of sv.

\section{REFERENCES}

1) Signwa, T., Kuruma, I., Takatsuka, K. and Takagi, H.: Folia pharmac. jap. 66, 400 (1970)

2) WHITTAKER, V.P.: Biochom. J. 72, 694 (1959)

3) Johnson, M.K. avd Whittaker, V.P.: Acta neurol. scand. suppl. 1, 38, 60 (1962)

4) Segawa, T. and Kuruma, I.: J. Pharm. Pharmac. 20, 320 (1968)

5) Segawa, T., Kuruma, I., Takatsuka, K. and Takagi, H.: J. Pharm. Pharmac, 20, 801 (1968)

6) Lowry, O.H., Rosebrougit, N.J., FArr, A.L. AND RandAll, R.J.: J. biol. Chom. 193, 265 (1951)

7) Snyder, S.H., Axelrod, J. And Zweig, M.: Biochem. Pharmac. 14, 831 (1965)

8) Inouyf, A., Kataoka, K. And Shinagawa, J.: Nature, Lont. 198, 291 (1963)

9) Gillis, C.N., Giarman, N.J. And Freedman, D.X.: Biochem. Pharmac. 13, 1457 (1964)

10) Robinson, J.D., Anderson, J.H. and Grekn, J.P.: J. Pharmac. exp. Ther. 147, 236 (1965)

11) Hillarp, N.-A. aNd Malmfors, T.: Life Sci. 3, 1067 (1964)

12) Dahlström, A., Fuxe, K. AND Hillarp, N.-A.: Acta pharmac. tox. 22, 277 (1965) 
13) Carlsson, A. And Whldeck, B.; Acta pharmac. tox. 22, 293 (1965)

14) Malmfors, T.: Acta physiol. scand. 64, supp!. 248 (1965)

15) Costa, E., Boullin, D.J., Hammer, W., Vogel, W. and Brodie, B.B.: Phamac. Rev. 18, 577 (1966)

16) Takatsuka, K., Segawa, T. and Takagi, H.: J. Neurochem. 17, 695 (1970)

17) SEgawa, T.: Iap. J. Pharmac. 20, 87 (1970)

18) Wise, C.D. And Ruelius, H.W.: Biochem. Pharmac. 17, 617 (1968)

19) De Robertis, E., Rodriguez de lores Arnaiz, G. àd Pellegrino de Iraldi, A.: Nature, Lond. 194, 794 (1962)

20) De Robertis, E., Rodrigulz de Lores arnaiz, G., Salganicoff, L., Pellegrino de Iraldi, A. AND Zieher, L.M.: J. Neurochem. 10, 225 (1963)

21) Hillarp, N. $-\Lambda$. and Thieme, G.: Acta physiol. scand. 45, 328 (1959)

22) Pottri, L.T. and Axelrod, J.: J. Pharmac, exp. Ther. 142, 299 (1963)

23) Potter, L.T.: Pharmac. Rev. 18, 439 (1966)

24) Weintr, N. And Jardetzky, O.: Arch. exp. Path. Pharmak. 248, 308 (1964)

25) Parrot, J.L. and Lamorde, C.: C. r. Séanc. Soc. Biol. 145, 1047 (1951)

26) Parrot, J.L., Nicot, G. and Labordl, C.: C. r. Sianc. Soc. Biol. 154, 1426 (1960)

27) Werlf, E. and Amann, R.: Klin. Wscir, 34, 624 (1956)

28 Sanyal, R.K. and Wrst, G.B.: J. Pharm. Pharmac. 11, 548 (1959)

29) Kobayasu, Y.: Arch. Biochem. 96, 20 (1962)

30) Carisson, A., Hilt.arr, N.-A. ANd Waldeck, B.: Acta physiol, scand. 59, suppl. 215 (1963)

31) Obianwu, H.O.: I. Pham. Phamac. 19, 54 (1967) 